\title{
PENGETAHUAN, SIKAP DAN PRAKTIK SWAMEDIKASI PADA MAHASISWA UNIVERSITAS BALI INTERNASIONAL
}

\section{(KNOWLEDGE, ATTTUDE, PRACTICE SELF-MEDICATION AMONG STUDENT OF UNIVERSITY BALI INTERNATIONAL)}

\author{
DEWI PUSPITA APSARI ${ }^{1}$, MADE KRISNA ADI JAYA ${ }^{2}$, NI PUTU WINTARIANI ${ }^{1}$, \\ NI PUTU ARYATI SURYANINGSIH ${ }^{1}$ \\ ${ }^{1}$ Prodi Farmasi Klinis, Universitas Bali Internasional, Denpasar-Bali \\ ${ }^{2}$ Prodi Farmasi, Universitas Udayana, Denpasar-Bali
}

\begin{abstract}
Abstrak: Swamedikasi bila dilakukan secara irasional dapat menimbulkan masalah seperti efek samping obat. Hal tersebut dapat diturunkan dengan meningkatkan pengetahuan masyarakat, dimana hal tersebut terwakilkan dari pengetahuan mahasiswa. Oleh karena itu penelitian ini bertujuan untuk mengevaluasi pengetahuan, sikap dan praktik swamedikasi mahasiswa Farmasi dan Non-Farmasi di Universitas Bali Internasional. Penelitian ini menggunakan desain cross-sectional. Instrumen kuisioner yang mengandung 20 pertanyaan digunakan pada penelitian. Data dianalisis menggunakan SPSS (21.0). Chi-square test digunakan untuk membandingkan distribusi proporsi tiap kelompok sampel. Prevalensi swamedikasi antara mahasiswa Farmasi $(77,4 \%)$ dan Non-Farmasi $(40,4 \%)$ berbeda signifikan $(\mathrm{p}=0,000)$. Pengetahuan dan Praktik swamedikasi mahasiswa Farmasi signifikan lebih tinggi dibandingkan mahasiswa Non-Farmasi. Gejala flu merupakan indikasi obat yang paling banyak digunakan oleh mahasiswa Farmasi dan Non-Farmasi (43,1\%). Mahasiswa Non-Farmasi $(24,8 \%)$ signifikan $(\mathrm{p}=0,001)$ lebih tinggi menganggap penggunaan antibiotika aman untuk swamedikasi dibandingkan mahasiswa Farmasi $(5,1 \%)$. Terdapat perbedaan signifikan lebih tinggi pengetahuan dan praktik swamedikasi pada mahasiswa Farmasi dan Non-Farmasi.
\end{abstract}

Kata kunci: mahasiswa, pengetahuan, praktik, sikap, swamedikasi.

Abstract : Irrational self- medication can cause problems such as side effects of the drug. Students' improved knowledge may reduce irrational self-medication, where it is represented from the knowledge of the students. This study aims to evaluate self-medication and its pattern among different groups of University Bali International students. This cross-sectional study used a questionnaire consisting 20 questions to know the knowledge, attitude and practice self-medication among pharmacy and other health students. Chi-square test was used to compare the distribution of proportions. The prevalence of self-medication within the study period was significance $(\mathrm{p}=0,000)$ different between Pharmacy students $(77,4 \%)$ and other health students $(40,4 \%)$. Pharmacy students significance had better knowledge and practice about self-medication compared to other health students. Cold and flu symptoms were the most common indication among pharmacy and other health students $(43,1 \%)$. Other health students $(24,8 \%)$ significantly $(\mathrm{p}=0,001)$ higher safety beliefs on antibiotics used in self-medication compared with pharmacy students $(5,1 \%)$. Pharmacy students significantly had better knowledge and practice about self-medication compared to other health students

Keywords: knowledge, attitude, practice, self-medication, student

\section{PENDAHULUAN}

Konsumsi obat yang tepat sebaiknya dimonitor oleh tenaga kesehatan sehingga apabila timbul efek obat yang tidak diinginkan, tenaga kesehatan dapat dengan segera mendiagnosa dan meresepkan obat lain untuk mengatasi masalah tersebut (Ahmad et al., 2014). Sesuai data Riset Kesehatan Dasar (Riskesdas) Tahun 2013, sebesar $35,2 \%$ rumah tangga di Indonesia menyimpan obat untuk swamedikasi. Dari 35,2\% rumah tangga yang menyimpan obat, sebesar $35,7 \%$ menyimpan obat keras dan $27,8 \%$ menyimpan antibiotik.
Selain itu juga dari jumlah tersebut, $81,9 \%$ menyimpan obat keras dan 86,1\% menyimpan antibiotik yang diperoleh tanpa resep (Kementerian Kesehatan RI, 2013). Data ini jelas menunjukkan bahwa sebagian perilaku swamedikasi di Indonesia masih irasional.

Swamedikasi dapat dibagi menjadi dua yaitu swamedikasi yang rasional dan irasional(AlRaddadi, 2017). Salah satu bentuk swamedikasi yang irasional adalah penggunaan obat-obat yang seharusnya diresepkan secara bebas (AlRaddadi et al.,, 2017). Suatu studi di Portugal

• correspondence email: dewipuspitaapsari@gmail.com 
menemukan bahwa rendahnya tingkat pengetahuan mahasiswa dalam penggunaan antibiotik yang tepat. Rendahnya tingkat pengetahuan ini juga akan berkontribusi pada swamedikasi yang irasional (Alam dkk., 2015). Swamedikasi yang irasional dipercaya mengakibatkan efek samping pengobatan, interaksi obat yang serius, diagnosis diri atau dosis obat yang salah, menutupi penyebab mendasar dari penyakit, risiko toksisitas, ketergantungan obat dan peningkatan kejadian resistensi antibiotika (AlRaddadi K et al., 2017). Salah satu langkah yang dapat dilakukan untuk menurunkan kejadian swamedikasi yang irasional adalah dengan meningkatkan pengetahuan masyarakat(Gyawali et al., 2015).

Pengetahuan masyarakat mengenai swamedikasi dapat terwakilkan dari pengetahuan mahasiswa mengenai hal tersebut, karena pelaksanaan swamedikasi pada mahasiswa lebih sering dibandingkan masyarakat umumnya (Almasdy and Sharrif, 2011). Mahasiswa kesehatan sering melakukan swamedikasi karena tingkat pendidikan yang tinggi serta memiliki akses lebih tinggi pada informasi mengenai kesehatan, obat dan penyakit. Mahasiswa kesehatan sebaiknya memiliki pengetahuan yang baik terkait swamedikasi sehingga di masa yang mendatang mereka mampu melakukan praktik swamedikasi yang rasional serta mampu menganjurkan, memotivasi dan memberitahukan pengetahuan kepada pasien dan masyarakat umum mengenai praktik swamedikasi yang rasional (Gyawali et al., 2015). Berdasarkan studi yang dilakukan oleh shivaraj et al., (2014), diketahui bahwa 78,35\% mahasiswa melakukan swamedikasi untuk penyakit flu dan batuk. Selain itu juga diketahui $63,91 \%$ mahasiswa mengkonsumsi antibiotika tanpa resep dokter (Patil et al., 2014). Studi terbaru di India menunjukkan insiden swamedikasi cukup tinggi pada mahasiswa kesehatan yakni sebesar $92 \%$.

Di Indonesia penelitian mengenai swamedikasi banyak dilakukan kepada masyarakat luas. Namun belum banyak penelitian yang dilakukan untuk melihat gambaran tingkat pengetahuan, sikap dan praktik mahasiswa kesehatan mengenai swamedikasi. Oleh karena itu, diperlukan penelitian untuk mengetahui gambaran tingkat pengetahuan, sikap dan praktik mahasiswa Universitas Bali Internasional mengenai swamedikasi.

\section{METODE PENELITIAN}

Penelitian ini merupakan penelitian deskriptif. Penelitian dengan desain survey cross sectional ini telah melalui uji kelaikan etik dengan nomor 001.01/UNBI/EC/IV/2020. Penelitian menggunakan kuesioner sebagai alat pengumpulan data. Kuisioner yang digunakan merupakan kuisioner terjemahan dari penelitian sebelumnya. Setelah dilakukan uji dengan SPSS 21, kuisioner yang digunakan telah valid dan realiable. Teknik sampling yang digunakan adalah simple random sampling. Jumlah sampel yang digunakan sebanyak 246 mahasiswa. Perhitungan sampel yang digunakan adalah sebagai berikut:

$$
\begin{gathered}
\mathrm{N}=\frac{P q}{L^{2}} x Z a^{2} \\
\mathrm{~N}=\frac{06 x 0,4}{0,05^{2}} x 1,96^{2} \\
\mathrm{~N}=246 \text { mahasiswa }
\end{gathered}
$$

Keterangan Rumus

$\mathrm{N}$ = sampel minimum yang harus terpenuhi

$\mathrm{P}=$ estimasi prevalensi swamedikasi pada

mahasiswa kesehatan yakni $60 \%$ atau 0,6

$\mathrm{q}=$ presisi $(1-\mathrm{P}$ atau 0,4$)$

$\mathrm{L}=$ margin error $(0,05)$

$\mathrm{Za}=$ konstanta $(1,96$ untuk CI 95\%)

Data kategorik dan outcome tiap variabel dipaparkan dalam bentuk deskriptif (frekuensi dan persentase). Pearson Chi-square tes digunakan untuk membandingkan proporsi distribusi antara dua kelompok.

\section{HASIL DAN PEMBAHASAN}

Karakteristik sampel. Proporsi swamedikasi pada studi ini ditemukan sebesar $77,4 \%$ pada mahasiswa Farmasi dan 40,4\% pada mahasiswa Non-Farmasi. Dari penelitian ini juga diketahui, $54,4 \%$ perempuan dan $45,5 \%$ laki-laki melakukan praktik swamedikasi. Hasil yang didapat sesuai dengan penelitian yang dilakukan di Bahrain dan Pakistan yakni proporsi swamedikasi yang dilakukan mahasiswa kesehatan di suatu universitas sebesar 44,8\% (James dkk., 2006) dan 76\% (Zafar dkk., 2008) secara berturut-turut. 
Tabel 1. Pengetahuan Mahasiswa Terkait Swamedikasi

\begin{tabular}{|c|c|c|c|c|c|c|}
\hline & \multirow{2}{*}{ Pertanyaan Pengetahuan Swamedikasi } & \multicolumn{2}{|c|}{ Farmasi } & \multicolumn{2}{|c|}{ Non-Farmasi } & \multirow{2}{*}{$\begin{array}{c}P- \\
\text { value }\end{array}$} \\
\hline & & Benar & Salah & Benar & Salah & \\
\hline 1. & $\begin{array}{l}\text { Obat antihipertensi merupakan salah satu jenis obat } \\
\text { yang dapat digunakan pada swamedikasi }\end{array}$ & $\begin{array}{c}38 \\
(27,7 \%)\end{array}$ & $\begin{array}{c}99 \\
(72,3 \%)\end{array}$ & $\begin{array}{c}56 \\
(51,4 \%)\end{array}$ & $\begin{array}{c}53 \\
(48,6 \%)\end{array}$ & 0,000 \\
\hline 2. & $\begin{array}{l}\text { Penggunaan antibiotika dapat dihentikan apabila } \\
\text { gejala panas dan nyeri tenggorokan telah membaik } \\
\text { apabila mengalami sakit tenggorokan }\end{array}$ & $\begin{array}{c}16 \\
(11,7 \%)\end{array}$ & $\begin{array}{c}121 \\
(88,3 \%)\end{array}$ & $\begin{array}{c}35 \\
(32,1 \%)\end{array}$ & $\begin{array}{c}74 \\
(67,9 \%)\end{array}$ & 0,000 \\
\hline 3. & $\begin{array}{l}\text { Antasida sebaiknya dikunyah terlebih dahulu } \\
\text { sebelum ditelan untuk mendapatkan efek } \\
\text { maksimum dari obat tersebut }\end{array}$ & $\begin{array}{c}126 \\
(92,0 \%)\end{array}$ & $\begin{array}{c}11 \\
(8,0 \%)\end{array}$ & $\begin{array}{c}82 \\
(75,2 \%)\end{array}$ & $\begin{array}{c}27 \\
(24,8 \%)\end{array}$ & 0,000 \\
\hline 4. & $\begin{array}{l}\text { Swamedikasi yang rasional penting dilakukan } \\
\text { untuk menekan biaya pengobatan }\end{array}$ & $\begin{array}{c}124 \\
(90,5 \%)\end{array}$ & $\begin{array}{c}13 \\
(9,5 \%)\end{array}$ & $\begin{array}{c}82 \\
(75,2 \%)\end{array}$ & $\begin{array}{c}27 \\
(24,8 \%)\end{array}$ & 0,001 \\
\hline 5. & $\begin{array}{l}\text { Merupakan langkah yang tepat apabila membeli } \\
\text { kembali obat yang telah diresepkan dokter untuk } \\
\text { mengatasi penyakit yang sama, terutama penyakit } \\
\text { kronis seperti hipertensi }\end{array}$ & $\begin{array}{c}48 \\
(35,0 \%)\end{array}$ & $\begin{array}{c}89 \\
(65,0 \%)\end{array}$ & $\begin{array}{c}59 \\
(54,1 \%)\end{array}$ & $\begin{array}{c}50 \\
(45,9 \%)\end{array}$ & 0,003 \\
\hline
\end{tabular}

Pengetahuan Mahasiswa Terkait Swamedikasi. Pada tabel 1. dapat dilihat terdapat perbedaan signifikan tingkat pengetahuan swamedikasi pada mahasiswa Farmasi dan Non-Farmasi, dimana mahasiswa Farmasi memiliki tingkat pengetahuan yang lebih tinggi. Hasil yang sama didapatkan pada penelitian yang dilakukan oleh Eissa et al., 2013, penelitian yang dilakukannya juga menunjukkan tingkat pengetahuan mahasiswa farmasi terkait swamedikasi jauh lebih tinggi dibandingkan mahasiswa Non-Farmasi (Eissa, 2013). Penyebab hal tersebut adalah karena mahasiswa Non-Farmasi tidak mendapatkan mata kuliah farmakologi dan tidak memahami masalah terkait obat.

Tabel 2. Indikasi Obat yang Digunakan untuk Swamedikasi

\begin{tabular}{lccc}
\hline Indikasi Obat & $\begin{array}{c}\text { Farmasi } \\
\text { n=137 (\%) }\end{array}$ & $\begin{array}{c}\text { Non- } \\
\text { Farmasi } \\
\text { n=109 }(\%)\end{array}$ & $\begin{array}{c}\boldsymbol{P} \text { - } \\
\text { Value }\end{array}$ \\
\hline Flu & $59(43,1)$ & $61(43,1)$ & 0,855 \\
Kolik & $1(0,7)$ & $0(0,7)$ & - \\
Panas & $56(40,9)$ & $54(40,9)$ & 0,849 \\
Sakit kepala & $48(35,0)$ & $46(35,0)$ & 0,837 \\
Mual/Muntah & $9(6,6)$ & $9(6,6)$ & 1 \\
Diare & $32(23,4)$ & $11(23,4)$ & 0,001 \\
Nyeri Haid & $24(17,5)$ & $9(17,5)$ & 0,009 \\
Spasme Otot & $2(1,5)$ & $1(1,5)$ & 0,564 \\
Infeksi Virus & $1(0,7)$ & $3(0,7)$ & 0,317 \\
dan Bakteri & $1(0,7)$ & & \\
\hline
\end{tabular}

\section{Praktik Mahasiswa Terkait Swamedikasi.}

Pada tabel 2 terlihat tiga indikasi obat teratas yang digunakan untuk swamedikasi yakni obat flu, panas dan sakit kepala. Setelah dilakukan uji statistik diketahui bahwa tidak terdapat perbedaan signifikan indikasi obat swamedikasi yang digunakan pada mahasiswa Farmasi dan NonFarmasi. Penelitian di Bahrain (James et al., 2006),
India (Shivaraj, Selvaraj and Ramalingam, 2014) dan Ethiopia (Eticha and Mesfin, 2014) juga menunjukkan hal yang sama, yakni mahasiswa paling banyak melakukan swamedikasi pada indikasi obat untuk sakit kepala, panas dan flu.

Golongan obat yang paling sering digunakan oleh mahasiswa dapat dilihat pada tabel 3 . Mahasiswa farmasi sering melakukan swamedikasi pada obat penurun panas $(59 \%)$, vitamin $(56,2 \%)$, pengobatan flu $(49,6 \%)$ dan analgesik $(31,4 \%)$. Sedangkan pada mahasiswa Non-Farmasi adalah penurun panas $(51,4 \%)$, pengobatan flu $(42,2 \%)$, vitamin $(39,4 \%)$ dan antibiotik $(28,4 \%)$. Penelitian yang dilakukan oleh AlRaddadi et al., 2017 juga mendapatkan hal yang sama yakni analgesik, pengobatan flu, penurun panas dan vitamin merupakan golongan obat yang paling sering digunakan untuk swamedikasi. Data menarik yang ditemukan pada penelitian ini adalah mahasiswa Non-Farmasi signifikan $(0,018)$ lebih tinggi menggunakan antibiotika untuk swamedikasi dibandingkan mahasiswa Farmasi. Alam (2015) mengatakan, hal ini disebabkan mahasiswa medis telah mempelajari penggunaan antibiotik yang tepat dan bahaya dari penyalahgunaan antibiotik. Penelitian yang dilakukan Haque et al., (2019) juga mendapatkan hal yang sama yakni mahasiswa nonmedis $(45,2 \%)$ signifikan lebih tinggi menggunakan antibiotik dibandingkan mahasiswa medis $(26,1 \%)$. Alasan yang mendasari tindakan tersebut adalah swamedikasi antibiotika lebih murah dan nyaman. Tingginya swamedikasi antibiotika secara bebas disebabkan lemahnya regulasi penggunaan antibiotika di negara kita. 
Tabel 3. Golongan Obat yang digunakan untuk Swamedikasi

\begin{tabular}{lccc}
\hline Indikasi Obat & $\begin{array}{c}\text { Farmasi } \\
\mathbf{n = 1 3 7} \\
(\boldsymbol{\%})\end{array}$ & $\begin{array}{c}\text { Non- } \\
\text { Farmasi } \\
\mathbf{n = 1 0 9}(\mathbf{\%})\end{array}$ & $\begin{array}{c}\boldsymbol{P} \text { - } \\
\text { Value }\end{array}$ \\
\hline Analgesik & $43(31,4)$ & $16(14,7)$ & 0,000 \\
Antibiotik & $15(10,9)$ & $31(28,4)$ & 0,018 \\
Pengobatan flu & $68(49,6)$ & $46(42,2)$ & 0,039 \\
Penurun Panas & $82(59,9)$ & $56(51,4)$ & 0,027 \\
Antasida & $25(18,2)$ & $13(11,9)$ & 0,052 \\
Antispasmodik & $12(8,8)$ & $8(7,3)$ & 0,371 \\
Aspirin & $4(2,9)$ & $0(0)$ & - \\
Krim & $14(10,2)$ & $6(5,5)$ & 0,074 \\
Vitamin & $77(56,2)$ & $43(39,4)$ & 0,002 \\
Herbal & $34(24,8)$ & $9(8,3)$ & 0,000 \\
\hline
\end{tabular}

Data pada tabel 4. menunjukkan golongan obat yang dipercaya aman digunakan untuk swamedikasi pada mahasiswa Farmasi dan NonFarmasi adalah vitamin, herbal dan pengobatan flu. Perbedaan terbesar dari kedua kelompok tersebut adalah pada keamanan penggunaaan antibiotik. Diketahui bahwa mahasiswa Non-Farmasi signifikan $(p=0,001)$ lebih tinggi menganggap penggunaan antibiotika aman untuk swamedikasi dibandingkan mahasiswa Farmasi. Praktik swamedikasi di Indonesia sebenarnya telah diatur oleh pemerintah dalam bentuk dikeluarkannya aturan mengenai Daftar Obat Wajib Apotek (DOWA). DOWA merupakan obat yang dapat diserahkan tanpa resep dokter. Untuk swamedikasi, antibiotik kurang mendapatkan aturan yang cukup jelas berdasarkan SK Menkes No. 347 tahun 1990, karena tidak semua antibiotik masuk sebagai DOWA. Antibiotik yang masuk DOWA hanya dalam bentuk sediaan salep dan cair. Berdasarkan Undang-Undang Obat Keras St. No. 419 tgl. 22 Desember 1949, antibiotik termasuk obat keras (daftar G). Untuk distribusi obat daftar G diketahui bahwa penyerahan dan atau penjualan untuk keperluan pribadi adalah dilarang. Oleh karena itu penggunaan antibiotik tanpa resep dokter pada dasarnya adalah melanggar peraturan pemerintah baik Undang-Undang obat keras maupun SK Menkes tahun 1990. Tingginya angka mahasiswa Non-Farmasi yang menganggap antibiotika aman digunakan untuk swamedikasi menuntut kedepannya perlu dilakukan semacam edukasi penggunaan antibiotik dengan bijak. Edukasi menggunakan antibiotik secara bijak memang bukan tugas pemerintah saja, namun dibutuhkan sinergi dan sikap proaktif dari semua pihak dalam pengawasan penggunaan antibiotik yang berlebihan. Termasuk sanksi hukum bagi pelanggar yang menjual bebas antibiotik dimanamana.

\begin{tabular}{|c|c|c|c|}
\hline Indikasi Obat & $\begin{array}{c}\text { Farmasi } \\
\mathbf{n}=137 \\
(\%)\end{array}$ & $\begin{array}{c}\text { Non- } \\
\text { Farmasi } \\
\mathrm{n}=109(\%)\end{array}$ & $\begin{array}{c}P- \\
\text { Value }\end{array}$ \\
\hline Analgesik & $61(44,5)$ & $15(13,8)$ & 0,000 \\
\hline Antibiotik & $7(5,1)$ & $27(24,8)$ & 0,001 \\
\hline Pengobatan flu & $70(51,1)$ & $45(41,3)$ & 0,020 \\
\hline Antipiretik & $61(44,5)$ & $19(17,4)$ & 0,000 \\
\hline $\begin{array}{l}\text { Pengobatan } \\
\text { Alergi }\end{array}$ & $25(18,2)$ & $10(9,2)$ & 0,011 \\
\hline Antasida & $31(22,6)$ & $9(8,3)$ & 0,001 \\
\hline $\begin{array}{l}\text { Mual dan } \\
\text { Muntah }\end{array}$ & 0 & $3(2,8)$ & - \\
\hline Antidiare & $56(40,9)$ & $17(15,6)$ & 0,000 \\
\hline Antikolik & $0(0)$ & $0(0)$ & - \\
\hline Antispasmodik & $5(3,6)$ & $0(0)$ & - \\
\hline Aspirin & $11(8)$ & $3(2,8)$ & 0,033 \\
\hline Krim & $30(21,9)$ & $13(11,9)$ & 0,010 \\
\hline $\begin{array}{l}\text { Pil Kontrasepsi } \\
\text { Oral }\end{array}$ & $7(5,1)$ & $0(0)$ & - \\
\hline Vitamin & $108(78,8)$ & $58(53,2)$ & 0,000 \\
\hline Herbal & $77(56,2)$ & $30(27,5)$ & 0,000 \\
\hline
\end{tabular}

Sikap Mahasiswa Terkait Swamedikasi. Sikap terhadap swamedikasi adalah cara berfikir atau perasaan menetap mengenai tingkah laku atau praktik swamedikasi. Tabel 5 menunjukkan bahwa sikap mahasiswa Farmasi dan Non-Farmasi terkait swamedikasi tidak berbeda jauh, hal tersebut terlihat dari nilai signifikansi dari setiap pertanyaan yang ada. Tabel tersebut juga menunjukkan, mahasiswa Farmasi dan Non-Farmasi sama-sama memilki sikap yang baik dalam melakukan praktik swamedikasi. Sikap yang baik tersebut ditunjukkan dengan hampir sebagian besar mahasiswa mengetahui jika swamedikasi tidak kunjung menyembuhkan penyakitnya harus segera pergi ke dokter. Mahasiswa juga mengetahui bahwa swamedikasi hanya dapat dilakukan pada waktu singkat dan tidak boleh dilakukan pada penyakit kronis. Faktor yang menyebabkan sikap mahasiswa tersebut adalah karena mahasiswa yang dijadikan subjek penelitian merupakan mahasiswa kesehatan, sehingga mereka memiliki pengetahuan yang lebih terkait penyakit. 
Tabel 5. Sikap Mahasiswa Terkait Swamedikasi

\begin{tabular}{|c|c|c|c|c|}
\hline \multicolumn{2}{|r|}{ Sikap terkait Swamedikasi Mahasiswa } & \multirow[t]{2}{*}{$\begin{array}{c}\text { Farmasi } \\
\mathbf{n}=\mathbf{1 3 7}(\%)\end{array}$} & \multirow[t]{2}{*}{$\begin{array}{c}\text { Non-Farmasi } \\
n=109(\%)\end{array}$} & \multirow[t]{2}{*}{$\begin{array}{c}P- \\
\text { Value }\end{array}$} \\
\hline 1. & $\begin{array}{l}\text { Jika anda tidak yakin pada swamedikasi yang anda lakukan, } \\
\text { anda harus memeriksakan diri anda ke dokter }\end{array}$ & & & \\
\hline & Tidak Tahu & $0(0)$ & $2(1,8)$ & \\
\hline & Tidak Setuju & $0(0)$ & $1(0,9)$ & 0,148 \\
\hline & Setuju & $137(100)$ & $106(97,2)$ & \\
\hline \multirow[t]{4}{*}{2.} & $\begin{array}{l}\text { Swamedikasi pada periode waktu yang singkat merupakan hal } \\
\text { pantas yang dapat dilakukan }\end{array}$ & & & \\
\hline & Tidak Tahu & $21(15,3)$ & $18(16,5)$ & \\
\hline & Tidak Setuju & $14(10,2)$ & $19(17,4)$ & 0,222 \\
\hline & Setuju & $102(74,5)$ & $72(66,1)$ & \\
\hline \multirow[t]{4}{*}{3.} & $\begin{array}{l}\text { Merupakan hal yang aman jika menggunakan beberapa obat } \\
\text { pada waktu yang sama jika obat tersebut bermanfaat untuk } \\
\text { gejala penyakit yang berbeda }\end{array}$ & & & \\
\hline & Tidak Tahu & $9(6,6)$ & $18(16,5)$ & \\
\hline & Tidak Setuju & $80(58,4)$ & $69(63,3)$ & 0,005 \\
\hline & Setuju & $48(35,0)$ & $22(20,2)$ & \\
\hline \multirow[t]{4}{*}{4.} & $\begin{array}{l}\text { Merupakan hal yang tepat apabila melakukan swamedikasi } \\
\text { untuk mengobati penyakit kronis seperti diabetes dan hipertensi. }\end{array}$ & & & \\
\hline & Tidak Tahu & $4(2,9)$ & $17(16,6)$ & \\
\hline & Tidak Setuju & $103(75,2)$ & $74(67,9)$ & 0,002 \\
\hline & Setuju & $30(21,9)$ & $18(16,5)$ & \\
\hline \multirow[t]{4}{*}{5.} & $\begin{array}{l}\text { Dalam hal mengatasi kekambuhan penyakit kronis seperti alergi } \\
\text { dan asam urat hal yang tepat apabila menggunakan kembali obat } \\
\text { yang pernah diresepkan sebelumnya oleh dokter }\end{array}$ & & & \\
\hline & Tidak Tahu & $7(5,1)$ & $11(10,1)$ & \\
\hline & Tidak Setuju & $70(51,1)$ & $43(39,4)$ & 0,109 \\
\hline & Setuju & $60(43,8)$ & $55(50,5)$ & \\
\hline
\end{tabular}

\section{SIMPULAN}

Terdapat perbedaan signifikan lebih tinggi pengetahuan dan praktik swamedikasi pada mahasiswa Farmasi dan Non-Farmasi. Oleh karena itu kedepannya perlu dilakukan semacam edukasi penggunaan antibiotik dengan bijak oleh tenaga kesehatan.

\section{UCAPAN TERIMA KASIH}

Ucapan terima kasih diberikan semua pihak yang membantu dalam penyelesaian jurnal ini terutama kepada mahasiswa Universitas Bali Internasional yang sudah berpatisipasi dalam penelitian ini.

\section{DAFTAR PUSTAKA}

Ahmad, A., Patel, I., Mohanta, G. and Balkrishnan, R. (2014). Evaluation of Self Medication Practices in Rural Area of Town Sahaswan at Northern India. Annals of Medical and Health Sciences Research, 4(Suppl 2). pp. S73-S78.
Alam, N., Saffoon, N. and Uddin, R. (2015). Selfmedication among medical and pharmacy students in Bangladesh. BMC Research Notes, 8.

Almasdy, D. and Sharrif, A. (2011). SelfMedication Practice with Nonprescription Medication among University Students: a review of the literature. Archives of Pharmacy Practice. 2(3). pp. 95-100.

AlRaddadi. (2017). Determinants of selfmedication among undergraduate students at King Saud University: Knowledge, attitude and practice. Journal of Health Specialties, 5(2), pp. 95-101.

Eissa, A. (2013). Knowledge, Attitudes and Practices towards Medication Use among Health Care Students in King Saud University. The International Journal of Medical Students. 1st edn. Riyadh, I, pp. 6669. 
Eticha, T. and Mesfin, K. (2014). Self-medication practices in Mekelle, Ethiopia. PloS one. Public Library of Science, 9(5)

Gyawali, S., Shankar, P. R., Poudel, P. P. and Saha, A. (2015). Knowledge, Attitude and Practice of Self-Medication Among Basic Science Undergraduate Medical Students in a Medical School in Western Nepal. Journal of Clinical and Diagnostic Research: JCDR, 9(12), p. FC17-FC22.

Haque, M. et al. .(2019). Self-medication of antibiotics: Investigating practice among university students at the Malaysian national defence university. Infection and Drug Resistance. Dove Medical Press Ltd., 12, pp. 1333-1351

James, H., Handu, S. S., Al Khaja, K. A. J., Otoom, S. and Sequeira, R. P. (2006). Evaluation of the Knowledge, Attitude and Practice of SelfMedication among First-Year Medical Students. Medical Principles and Practice, 15(4), pp. 270-275
Kementerian Kesehatan RI . (2013). Riset Kesehatan Dasar (Riskesdas). Badan Penelitian dan Pengembangan Kesehatan.

Patil, S. B., S. H., V., B.V., P., Santoshkumar, J., Binjawadgi, A. S. and Kanaki, A. R. (2014). Self-Medication Practice and Perceptions Among Undergraduate Medical Students: A Cross-Sectional Study. Journal of Clinical and Diagnostic Research: JCDR, 8(12), p. HC20-HC23.

Shivaraj G., Selvaraj, K. and Ramalingam, A. (2014). Prevalence of self-medication practices and its associated factors in Urban Puducherry, India. Perspectives in Clinical Research, 5(1), p. 32.

Zafar, S. N., Syed, R., Waqar, S., Zubairi, A. J., Vaqar, T., Shaikh, M., Yousaf, W., Shahid, S. and Saleem, S. .(2008). Self-medication amongst university students of Karachi: prevalence, knowledge and attitudes. JPMA. The Journal of the Pakistan Medical Association, 58(4), pp. 214-7. 